\title{
COMPARISON OF STEM VOLUME OF EASTERN WHITE PINE (PINUS STROBUS L.) AND SCOTCH PINE (PINUS SYLVESTRIS L.)
}

\author{
Petr Vaněk, Pavel Bednár̆
}

Received: September 19, 2012

\begin{abstract}
VANĚK PETR, BEDNÁŘ PAVEL: Comparison of stem volume of Eastern white pine (Pinus strobus L.) and Scotch pine (Pinus sylvestris L.). Acta Universitatis Agriculturae et Silviculturae Mendelianae Brunensis, 2013, LXI, No. 1, pp. 221-226

This study deals with mensurational and volumetric characteristics of introduced Eastern white pine (Pinus strobus) in comparison with native Scotch pine (Pinus sylvestris) of the similar age and habitat. Municipal forests of Hradec Králové city (an area with the natural occurrence of Scotch pine and introduced Eastern white pine; east part of Bohemia, altitude from 250 to $280 \mathrm{~m}$ a.s.l.) belong to typological unit - nutrient-very poor, and acidic sites. There comparative analysis of basic stem variables (stem diameter at the breast-height - DBH, total tree height $-\mathrm{H}$ and stem volume $-\mathrm{V}$ ) of dominant trees (10 individuals with the highest DBH of both species) in four suitable forest stands of age from 42 to 102 years was done. Statistical analysis showed similar trends in all forests stands. Eastern white pine compared to Scotch pine reached larger mean DBH (up to 16\%). H - values do not have a clear trend across the forest stands and did not show large differences in all cases. Eastern white pine compared to Scotch pine showed also larger mean stem volume (up to 47\%). Therefore, introduced Eastern white pine reached higher stem size parameters and wood production compared to native Scotch pine in studied forest district.
\end{abstract}

Eastern white pine, Scotch pine, stem volume, Pinus strobus, Pinus sylvestris

Eastern white pine (Pinus strobus), also called northern white pine, is one of the most valuable tree species in eastern North America. Because it belongs among the fast growing northern conifers, it is an excellent tree for reforestation projects, landscaping, and Christmas trees production and it is widely planted in America (Burns, HonKala, 1990). Eastern white pine is distributed from Newfoundland west to extreme southeastern Manitoba and south to the Great Lake States, along the Atlantic seaboard to New Jersey, and in the Appalachian Mountains to northern Georgia. It also occurs in Iowa, western Kentucky, western Tennessee, and Delaware (LitTLe, 1979; Burns, Honkala, 1990). Eastern white pine frequently dominates or codominates in xeric northern pine forests. In mixed hardwood forests, it often occurs as a scattered dominant tree towering above the surrounding hardwoods (OHMANN, 1979).
It can be found in both mixed stands (with red spruce, hemlock, yellow birch or sugar maple) and pure stands. White pine grows on nearly all the soils within its range, but generally competes best on well drained sandy soils of low to medium site quality. These soils permit fair growth of white pine but not hardwoods. On these sandy sites, white pine regenerates naturally, competes easily, and can be managed most effectively and economically. Eastern white pine has relatively wide ecological amplitude - the climate over the range of white pine is cool and humid. The distribution of white pine coincides reasonably with that part of eastern North America where the July temperature averages between 18 and $23{ }^{\circ} \mathrm{C}$. Annual precipitation ranges from about $510 \mathrm{~mm}$ in northern Minnesota to about $2030 \mathrm{~mm}$ in northwestern Georgia (BuRNs, HonKaLA, 1990). In northern part of the range white pine grows from sea 
level to a height about 500 meters above sea level, in southern part of the range from 400 meters to 1200 meters above sea level (ÚRADNíčEK, 2003). White pine is intermediate in shade tolerance. Although it will tolerate up to 80 percent shade, tree growth increases as shade is reduced (BALmer, Williston, 1983). It can achieve maximum height growth in as little as 45 percent of full sunlight (Struve, TALBERT, MCKEAND, 1984).

Early white pine growth is slow. Open-grown trees are about $30 \mathrm{~cm}$ high when 5 years old; and $137 \mathrm{~cm}$ high when 8 to 10 years old. Thereafter, height growth may be quite rapid. Between 10 and 20 years old, open-grown dominant trees have grown as much as $137 \mathrm{~cm}$ in height in a single year. Annual increments of $91 \mathrm{~cm}$ are not uncommon, but average height growth of dominant trees during this period is about $41 \mathrm{~cm}$. By age 55 , annual height growth is about $0.3 \mathrm{~m}$. Diameter growth may be very different, but dominant trees ordinarily grow 0.4$0.5 \mathrm{~cm}$ per year (FowELLs, 1965). The average white pine stand in New England grows from 4.2 to 11.2 $\mathrm{m}^{3}$ /ha per year depending on age and site index and yields of about $504 \mathrm{~m}^{3} / \mathrm{h}$ a at 50 years in nearly fully stocked managed stands are entirely possible (LANCASTER, LEAK, 1978). It is reported very good growth of Eastern white pine from all European countries where this species has been introduced in the past. For example in Germany, Eastern white pine achieves very good results in comparison with Scotch pine. The average stem volume is about $25 \%$ larger at the age of 50 years (WALHERR, 2000).

Eastern white pine was brought to the Europe for the first time in 1605 by G. Weymouth, but the first successful introduction was realized hundred years later - in 1705 (England) (MusiL, Hamerník, 2007). First record about cultivation of this species in our country is from 1785 (castle park, Lány), in the forest stands is used since the end of 18. century (first area was around Česká Kamenice). Currently the Eastern white pine grows from lowlands to foothills areas with optimum to approx. 500 meters above sea level on humid loamy and sandy soils in the Czech Republic (MLíkovskÝ, STÝBLo, 2006). White pine grows approx. on 35000 ha of total forest area (ŠINDELÁR̆, FRÝDL, 2004). This species is currently fully established and locally abundant in our country, grows mainly in single tree mixture or in group mixture (monoculture is not recommended) usually with Scotch pine or Norway spruce (MusiL, HAMERNÍK, 2007). In some areas (mainly national park České Švýcarsko and neighbourhood), Eastern white pine behaves as an invasive tree species. White pine is fundamentally changing species composition and spatial structure of natural Scotch pine stands there by very strong natural regeneration (HADINCOVÁ et al., 1997; Hadincová et al., 2008; Klitsch, Härtel, 2004). But on most other sites, the situation is different because in contrast to national park, Scotch pine is regenerated on relatively large clear cuttings (1 ha), where the Eastern white pine practically does not regenerate, i.e., the spreading of this species in commercial forests is more or less under control.

Main goal of this paper is comparison of mensurational and volume characteristics between dominant individuals of native Scotch pine and introduced Eastern white pine of the similar age and habitat.

\section{MATERIAL AND METHODS}

\section{Analysed area}

The investigated Eastern white pine/Scotch pine stands are located in municipal forests of Hradec Králové city (east part of Bohemia) - this area is located approximately between cities Hradec Králové and Pardubice. This area is a typical example of forest property, where native Scotch pine and introduced Eastern white pine occur in forest stands together and create specific mixtures.

The area is situated in the sediment zone of Labe and Orlice rivers with typical large terraces of acid fluvial sandy gravels, in patches with thin layer of drift sands (CUleK, 1996). Typical predominant soil types of this area are Podzols and Cambisols. The main part of the area can be ranked among warm regions (climatic region T2) (QUITT, 1971) with mean annual air temperature $8.5^{\circ} \mathrm{C}$ and mean annual sum of precipitation $615 \mathrm{~mm}$. According to silvicultural classification, the presented forest stands are classified as $1 \mathrm{P}$ - Betuleto-Quercetum variohumidum acidophilum (Acidic Birch-Oak), 2M - FagetoQuercetum oligotrophicum (Nutrient-very poor BeechOak), and 2P - Quercetum abietinum variohumidum acidophilum (Acidic Oak) (PLÍvA, 1987) within beechoak altitudinal vegetation zone (alt. of chosen forest stands is from 250 to $280 \mathrm{~m}$ ).

\section{Stands description}

For evaluation of the differences in dimensional and volumetric characteristics between Scotch pine and Eastern white pine four forests stands with age range from 42 to 102 years were chosen (Tab. I-

I: Stand description - 86B4b

\begin{tabular}{|c|c|c|c|c|c|}
\hline \multirow{2}{*}{$\begin{array}{c}\text { Forests stand: } 86 \mathrm{~B} 4 \mathrm{~b} \\
\text { Species }\end{array}$} & \multicolumn{2}{|c|}{ Experimental plot size: $0.33 \mathrm{ha}$} & \multirow{2}{*}{$\begin{array}{c}\text { Age: } 42 \\
\begin{array}{c}\text { Number of } \\
\text { tress/ha }\end{array}\end{array}$} & \multirow{2}{*}{$\begin{array}{c}\text { Forest type group: } 2 \mathrm{M} \\
\text { Stock/ha } \\
{\left[\mathrm{m}^{3}\right]} \\
\end{array}$} & \multirow{2}{*}{$\begin{array}{c}\text { Stand density: } 13 \\
\text { Basal area/ha } \\
{\left[\mathrm{m}^{2}\right]}\end{array}$} \\
\hline & $\begin{array}{l}\text { Dominant } \\
\text { height }[\mathrm{m}]\end{array}$ & $\begin{array}{c}\text { Proportion of } \\
\text { studied species }\end{array}$ & & & \\
\hline Pinus strobus & 21.5 & $58 \%$ & 454 & 242 & 21.4 \\
\hline Pinus sylvestris & 22.7 & $42 \%$ & 436 & 164 & 16.2 \\
\hline Total & & & 890 & 406 & 37.6 \\
\hline
\end{tabular}


II: Stand description - 88A9

\begin{tabular}{lcccccc}
\hline Forests stand: 88A9 & \multicolumn{2}{c}{ Experimental plot size: $\mathbf{0 . 6 6}$ ha } & Age: 89 & Forest type group: 2M & Stand density: 9 \\
\hline Species & $\begin{array}{c}\text { Dominant } \\
\text { height [m] }\end{array}$ & $\begin{array}{c}\text { Proportion of } \\
\text { studied species }\end{array}$ & $\begin{array}{c}\text { Number of } \\
\text { tress/ha }\end{array}$ & $\begin{array}{c}\text { Stock/ha } \\
{\left[\mathbf{m}^{3}\right]}\end{array}$ & $\begin{array}{c}\text { Basal area/ha } \\
{\left[\mathbf{m}^{2}\right]}\end{array}$ \\
\hline Pinus strobus & 28.6 & $56 \%$ & 189 & 225 & 18.4 \\
Pinus sylvestris & 28.8 & $44 \%$ & 171 & 180 & 15.3 \\
\hline Total & & & $\mathbf{3 6 0}$ & $\mathbf{4 0 5}$ & $\mathbf{3 3 . 7}$ \\
\hline
\end{tabular}

III: Stand description - $41 B 9 a$

\begin{tabular}{lcccccc}
\hline Forests stand: 41B9a & \multicolumn{2}{c}{ Experimental plot size: $\mathbf{0 . 4 0}$ ha } & Age: $\mathbf{9 5}$ & Forest type group: IP & Stand density: 8 \\
\hline & $\begin{array}{c}\text { Species } \\
\text { hominant }\end{array}$ & $\begin{array}{c}\text { Proportion of } \\
\text { studied species }\end{array}$ & $\begin{array}{c}\text { Number of } \\
\text { tress/ha }\end{array}$ & $\begin{array}{c}\text { Stock/ha } \\
{\left[\mathbf{m}^{3}\right]}\end{array}$ & $\begin{array}{c}\text { Basal area/ha } \\
{\left[\mathbf{m}^{2}\right]}\end{array}$ \\
\hline Pinus strobus & 28.0 & $57 \%$ & 174 & 186 & 16.2 \\
Pinus sylvestris & 27.8 & $43 \%$ & 159 & 149 & 12.5 \\
\hline Total & & & 333 & 335 & 28.7 \\
\hline
\end{tabular}

IV: Stand description - 86B10b

\begin{tabular}{lccccc}
\hline Forests stand: 86B10b & \multicolumn{1}{c}{ Experimental plot size: $\mathbf{1 . 1 0}$ ha } & Age: 102 & Forest type group: 2P & Stand density: $\mathbf{6}$ \\
\hline Species & $\begin{array}{c}\text { Dominant } \\
\text { height }[\mathrm{m}]\end{array}$ & $\begin{array}{c}\text { Proportion of } \\
\text { studied species }\end{array}$ & $\begin{array}{c}\text { Number of } \\
\text { tress/ha }\end{array}$ & $\begin{array}{c}\text { Stock/ha } \\
{\left[\mathbf{m}^{3}\right]}\end{array}$ & $\begin{array}{c}\text { Basal area/ha } \\
{\left[\mathbf{m}^{2}\right]}\end{array}$ \\
\hline Pinus strobus & 29.8 & $61 \%$ & 62 & 156 & 11.6 \\
Pinus sylvestris & 26.8 & $39 \%$ & 65 & 100 & 9.2 \\
\hline Total & & & $\mathbf{1 2 7}$ & $\mathbf{2 5 6}$ & $\mathbf{2 0 . 8}$ \\
\hline
\end{tabular}

Tab. IV). In suitable parts of these stands (with occurrence of both Scotch pine and Eastern white pine) experimental plots were established. In these experimental plots both of these species grow on the same forest type group, have similar age and similar stand tending.

\section{Methodology}

In experimental plots within four forest stands all individuals of Eastern white pine and all individuals of Scotch pine were marked and recorded. Size of plots was dissimilar due to different sizes of forest stands and different occurrence of interest species and ranged from 0.33 ha in forest stand 86B4b to 1.10 ha in forest stand 86B10b (Tab. I-Tab. IV). Basic biometric variables - the stem diameter at the breast-height (i.e. $1.3 \mathrm{~m}$ above the ground surface; $\mathrm{DBH})$ and the total stem height $(\mathrm{H})$ of all trees on experimental plots were measured. To determine production potential and to find the difference in stem volume of species methodology of KANTOR (2008, 2009) was used. I.e., in each of experimental plot 10 dominant individuals of Eeastern white pine and 10 dominant individuals of Scotch pine with the highest DBH were chosen (exclusion of the subjective approach in the selection of individuals, minimization of the possible impacts of previous silvicultural measures). Edge trees, trees along corridors, roads etc. were excluded from the evaluation. Only trees within forest stand were included in the comparison. Age sameness of selected individuals within experimental plots was verified by dendrochronological analysis.
Finally, stem volume (V) of these selected trees was measured. For this purpose remote measuring of the entire stem profile (1 meter step) of each selected tree was used (Field-Map technology). This technology directly calculated stem volume from measured stem profile.

All statistical analyses of measured variables were performed using program Statistica 8.0 (Statsoft, Inc., Tusla, OKLahoma, 2007). Firstly, descriptive statistics of samples were calculated (particularly location characteristics and variability characteristics), after that the null hypothesis that a samples came from a normally distributed parent population was tested using normal probability plot (including Shapiro-Wilk test). Then comparison of measured and calculated data between selected Eastern white pine and Scotch pine trees was evaluated. For confirmation of existence of some statistically significant differences between DBH, $\mathrm{H}$ and $\mathrm{V}$ of species, parametric two-sample t-test (in case that samples had normal distribution) or distribution-free Mann-Whitney test (in case that samples had not normal distribution) were used. The significance level for rejection of the null hypothesis was at $\mathrm{p} \leq 0.05$ for all comparisons.

\section{RESULTS AND DISCUSSION}

On the experimental plot (0.33 ha) in the youngest forest stand 86B4b, 150 individuals of Scotch pine and 144 individuals of Eastern white pine were measured and analyzed. The results of descriptive statistics of 10 individuals with highest DBH of each 
V: Mean values of measured parameters and tests criterions

\begin{tabular}{|c|c|c|c|c|c|c|c|}
\hline $\begin{array}{l}\text { Forest } \\
\text { stand }\end{array}$ & Species & $\begin{array}{c}\text { Stem } \\
\text { diameter } \\
{[\mathrm{cm}]} \\
\text { Mean value }\end{array}$ & $\begin{array}{c}\text { Stem } \\
\text { diameter } \\
\text { Test criterion }\end{array}$ & $\begin{array}{c}\text { Stem height } \\
{[\mathrm{m}]} \\
\text { Mean value }\end{array}$ & $\begin{array}{l}\text { Stem height } \\
\text { Test criterion }\end{array}$ & $\begin{array}{c}\text { Stem volume } \\
{\left[\mathrm{m}^{3}\right]} \\
\text { Mean value }\end{array}$ & $\begin{array}{l}\text { Stem volume } \\
\text { Test criterion }\end{array}$ \\
\hline \multirow{2}{*}{$86 \mathrm{~B} 4 \mathrm{~b}$} & Pinus sylvestris & $29.4 \pm 1.3$ & \multirow{2}{*}{0.00018} & $22.7 \pm 0.9$ & \multirow{2}{*}{0.21292} & $0.73 \pm 0.07$ & \multirow{2}{*}{0.00149} \\
\hline & Pinus strobus & $33.4 \pm 2.3$ & & $22.0 \pm 1.2$ & & $0.99 \pm 0.14$ & \\
\hline \multirow{2}{*}{ 88A9 } & Pinus sylvestris & $42.6 \pm 1.5$ & \multirow{2}{*}{0.00006} & $28.4 \pm 3.9$ & \multirow{2}{*}{0.60902} & $1.83 \pm 0.16$ & \multirow{2}{*}{0.00066} \\
\hline & Pinusstrobus & $48.7 \pm 3.4$ & & $29.2 \pm 1.8$ & & $2.32 \pm 0.33$ & \\
\hline \multirow{2}{*}{$41 \mathrm{~B} 9 \mathrm{a}$} & Pinus sylvestris & $37.5 \pm 1.6$ & \multirow{2}{*}{0.00001} & $27.4 \pm 2.1$ & \multirow{2}{*}{0.86392} & $1.36 \pm 0.12$ & \multirow{2}{*}{0.00319} \\
\hline & Pinus strobus & $43.2 \pm 1.8$ & & $27.2 \pm 2.2$ & & $1.85 \pm 0.20$ & \\
\hline \multirow{2}{*}{ 86BlOb } & Pinus sylvestris & $52.4 \pm 1.46$ & \multirow{2}{*}{0.00016} & $27.2 \pm 2.0$ & \multirow{2}{*}{0.06371} & $2.68 \pm 0.25$ & \multirow{2}{*}{0.00038} \\
\hline & Pinus strobus & $60.8 \pm 6,65$ & & $29.6 \pm 3.1$ & & $3.95 \pm 1.22$ & \\
\hline
\end{tabular}

species (Tab. V) showed that mean stem diameter at the breast-height of Eastern white pine was 13.6\% larger $(33.4 \mathrm{~cm}$ vs. $29.4 \mathrm{~cm})$ contrarily, the average stem height of Eastern white pine was slightly lower (22.0m vs. $22.7 \mathrm{~m}$ - diff. 3.2\%). The biggest difference was observed in the mean stem volume Eastern white pine had this parameter 25.3\% larger $\left(0.99 \mathrm{~m}^{3}\right.$ vs. $\left.0.79 \mathrm{~m}^{3}\right)$. Differences between species in parameters of the mean stem diameter and mean stem volume were statistically significant.

Experimental plot (0.66 ha) in forest stand 88A9 was represented by 56 individuals of Eastern white pine and 52 individuals of Scotch pine. Analysis of data of dominant trees showed that Eastern white pine had $14.3 \%$ larger stem diameter $(48.7 \mathrm{~cm}$ vs. $42.6 \mathrm{~cm}$ ), mean stem height of Eastern white pine was fractionally higher $(29.2 \mathrm{~m}$ vs. $28.4 \mathrm{~m}$ - diff. $2.8 \%)$. The mean stem volume of Eastern white pine exceeded (26.8\%) mean stem volume of Scotch pine $\left(2.32 \mathrm{~m}^{3}\right.$ vs. $\left.1.83 \mathrm{~m}^{3}\right)$. Differences in the parameters of the mean stem diameter and mean stem volume were statistically significant.

On the experimental plot (0.40 ha) in forest stand 41B9a, 62 individuals of Scotch pine and 68 individuals of Eastern white pine were measured and analyzed. Results of descriptive statistics of dominant trees showed that mean stem diameter in breast-height of Eastern white pine was 15.2\% larger than diameter of Scotch pine $(43.2 \mathrm{~cm}$ vs. $37.5 \mathrm{~cm})$. The mean stem height of Eastern white pine was slightly lower than height of Scotch pine $(27.2 \mathrm{~m}$ vs. $27.4 \mathrm{~m}$ - diff. 0.7\%). Mean stem volume of Eastern white pine was $36.0 \%$ larger $\left(1.85 \mathrm{~m}^{3}\right.$ vs. $\left.1.36 \mathrm{~m}^{3}\right)$ than mean stem volume of Scotch pine. Statistical tests confirmed a statistically significant difference in the parameters of the mean stem diameter and mean stem volume.

Experimental plot (1.10 ha) in the forest stand $86 \mathrm{~B} 10 \mathrm{~b}$ was represented by 71 individuals of Scotch pine and 68 individuals of Eastern white pine. Analysis of data of dominant trees showed that Eastern white pine had 16.0\% larger mean stem diameter $(60.8 \mathrm{~cm}$ vs. $52.4 \mathrm{~cm})$ and $8.8 \%$ larger mean stem height ( $29.6 \mathrm{~m}$ vs. $27.2 \mathrm{~m}$ ) than Scotch pine. The difference of mean stem volume between species in this stand was the biggest from all analysed experimental plots. The mean stem volume of Eastern white pine strongly exceeded (47.4\%) mean stem volume of Scotch pine $\left(3.95 \mathrm{~m}^{3}\right.$ vs. $\left.2.68 \mathrm{~m}^{3}\right)$. As in the previous cases, differences between species in parameters of the mean stem diameter and mean stem volume were statistically significant.

Very few studies deal with issue of volume production of Eastern white pine (respectively, in comparison with native tree species) in conditions of Czech Republic, however, several studies confirm the generally valid conclusions of this paper. In the past, the authors of studies talked about Eastern white pine as a species with wide ecological amplitude with good economic efficiency (BEZECNÝ et al., 1981) and that this species reaches against the Scotch pine greater volume production practically in all habitats (ŠIKA, 1976). In several other studies, Eastern white pine is considered as a perspective species for introduction to our forest stands because of its sufficient volume production (BERAN, ŠINDELÁR̆, 1996; ŠINDELÁŘ, FRÝdL, 2004; KAŇÁK, 2004). Further results of studies from the area of Central Bohemia (Kostelec nad Černými lesy) state that the Eastern white pine is under appropriate conditions a highly productive tree species and it can even cope in volume production with Douglas fir (HART, 2009; TAuChmann, 2011). Study from national park České Švýcarsko - northern Bohemia (high occurrence of Eastern white pine, similar conditions as in municipal forests of Hradec Králové city) show, that this species has significantly larger increment than Scotch pine or other tree species in this area (KLITSCH, HÄrtel, 2004). Further results from the same area show that Eastern white pine reaches larger stem diameter and larger mean stem volume than Scotch pine (f.e. 25\% larger in 44 years old stand, 35\% larger in 71 years old stand and $46 \%$ larger in 114 years old stand), height of both species cannot be generalized (VACULі́, 2010). These results fully correspond with the conclusions of this paper.

\section{CONCLUSION}

On the basis of comparison of mensurational and volumetric characteristics of the dominant, similar 
old individuals of Eastern white pine and Scotch pine growing at the same location (same forest type group) it is possible to formulate following conclusions:

In all analyzed forest stands, dominant individuals of Eastern white pine reached larger mean stem diameter at the breast-height. These differences were statistically significant in all experimental plots. The size of these differences ranged from $13.6 \%$ to $16 \%$.

In parameter mean stem height was not found a general trend across forest stands, we cannot generally say that similar old dominant individuals of Eastern white pine or Scotch pine reached larger mean stem height at the same stand. However, differences between values were not statistically significant, therefore we can conclude that the height of both species is approximately similar.

Mean stem volume of dominant Eastern white pine trees was larger in all analyzed experimental plots than mean stem volume of dominant Scotch pine trees. In all cases differences between species were statistically significant. The size of these differences ranged from $25.3 \%$ to $47.4 \%$.

\section{SUMMARY}

There is very small number of research papers dealing with growth of Eastern white pine in Czech Republic. This paper focuses on the comparison of basic mensurational and volumetric characteristics between dominant individuals of Eastern white pine and Scotch pine in a chosen suitable forest stands with sufficient occurrence of both species in municipal forests of Hradec Králové city (east part of Bohemia, altitude from 250 to $280 \mathrm{~m}$ a.s.l.) - an area with the natural occurrence of Scotch pine and introduced Eastern white pine. In experimental plots within chosen forest stands all of individuals of Eastern white pine and all of individuals of Scotch pine were found. Basic biometric variables - the stem diameter at the breast-height $(\mathrm{DBH})$ and the total stem height $(\mathrm{H})$ of these trees were measured. To determine production potential and to find the difference in stem volume of species 10 dominant individuals of Eeastern white pine and 10 dominant individuals of Scotch pine with the highest DBH were chosen in each of experimental plot. Stem volume (V) of these selected trees were measured using Field-Map technology (remote measuring of the stem profile). Then statistical comparison of DBH, $\mathrm{H}$ and $\mathrm{V}$ between these species was performed. Statistical analyses showed that dominant individuals of Eastern white pine in comparison with similar old dominant individuals of Scotch pine growing at the same location reached significantly larger mean stem diameter at breast-height (difference ranged from $13.6 \%$ to $16 \%$ ), as well as in the case of the mean stem volume parameter, Eastern white pine reached in all forest stands higher values (difference ranged from $25.3 \%$ to $47.4 \%$ ). There was no clear trend in the differences between species in the parameter mean stem height, generally it cannot be said, which species reaches larger stem height, however, differences between values were not statistically significant, so it can be said, that the height of both species was at very similar level. Statistical evaluation of data clearly showed that introduced Eastern white pine reached higher stem size parameters and wood production comparing to native Scotch pine in conditions of municipal forests of Hradec Králové city.

\section{Acknowledgement}

This research was financially supported by Internal grant agency (IGA) MENDELU in Brno project No. 11/2011 - „Produkční potenciál borovice vejmutovky“.

\section{REFERENCES}

BALMER, W. E., WILLISTON, H. L., 1983: Managing eastern white pine in the Southeast. In: BURNS, R. M., HONKALA, B. H., 1990: Silvics Of North America Vol. 1 Conifers, Washington D.C., Agriculture Handbook 654, USDA Forest Service. $877 \mathrm{p}$.

BERAN, F., ŠINDELÁŘ, J., 1996: Perspektivy vybraných cizokrajných dřevin $\mathrm{v}$ lesním hospodářství České republiky. Lesnictví, 8: 357355. ISSN 1212-8449.

BEZECNÝ, P., 1981: Pěstování lesů, Státní zemědělské nakladatelství Praha, 328 p.
BURNS, R. M., HONKALA, B. H., 1990: Silvics Of North America Vol. 1 Conifers, Washington D.C., Agriculture Handbook No. 654, USDA Forest Service. $877 \mathrm{p}$.

CULEK, M., 1996: Biogeografické členění České republiky [1. díl], Praha, Enigma, 347 p. ISBN 8085368-80-3.

FOWELLS, H. A., 1965: Silvics of forest trees of the United States. Washington D.C., Agriculture Handbook No. 271, USDA Forest Service. 762 p.

HADINCOVÁ, V., DOBRÝ, J., HANZÉLYOVÁ, D., HÄRTEL, H., HERBEN, T., KRAHULEC, F., KYNCL, J., MORAVCOVÁ, L., ŠMILAUER, P., ŠMILAUEROVÁ, M., 1997: Invazní druh Pinus 
strobus v Labských pískovcích, Zprávy České Botanické Společnosti, 14: 63-79. ISSN 12115258.

HADINCOVÁ, V., KÖHLEINOVÁ, I., MAREŠOVÁ, J., ŠAJTAR, L., 2008: Šíření borovice vejmutovky v lesích České republiky, Živa, 3: 108-110. ISSN 0044-4812.

HART, V., 2009: Pěstování a produkční význam douglasky tisolisté (Pseudotsuga menziesii / Mirbel / Franco) na území ŠLP Kostelec nad Černými lesy, Disertační práce, FLD ČZU v Praze, 135 p.

KANTOR, P., 2008: Production potential of Douglas fir at mesotrophic sites of Krrtiny Training Enterprise. Journal of Forest Science, 7: 321-332. ISSN 1212-4834.

KANTOR, P., MAREŠ, R., 2009: Production potential of Douglas fir in acid sites of Hůrky Training Forest District, Secondary Forestry School in Písek. Journal of Forest Science 7: 312-322. ISSN 1212 4834.

KAŇÁK, J., 2004: Možnosti a úskalí introdukce některých druhů rodu Pinus, In: Perspektivy lesnické dendrologie a šlechtění lesních dřevin, Kostelec nad Černými lesy, ČZU v Praze, p. 76-84. ISBN 80-213-1164-9.

KLITSCH M., HÄRTEL H., 2004: Invaze borovice vejmutovky v Národním parku České Švýcarsko. In: Neuhöferová P. (ed.), Introdukované dřeviny a jejich produkční a ekologický význam, Praha, ČZU Praha, p. 109-112. ISBN 80-213-1234-3.

LANCASTER, K. F., LEAK W. B., 1978: A silvicultural guide for white pine in the Northeast. Gen. Tech. Rep. U. S. Department of Agriculture, Forest Service, Northeastern Forest Experiment Station. $13 \mathrm{p}$.

LITTLE, E. L., JR., 1979: Checklist of United States trees (native and naturalized). In: Carey, J. H. Pinus strobus. In: Fire Effects Information System [Online]. c1993, [cit. 6.6.2012] Available: <http://www.fs.fed. us/database/feis/plants/tree/pinstr/all.html\#31>.

MLÍKOVSKÝ J., STÝBLO P., 2006: Nepůvodní druhy fauny a flóry České republiky, Praha, ČsOP, 496 p. ISBN 80-86770-17-6.

MUSIL, I., HAMERNÍK, J., 2007: Jehličnaté dřeviny: přehled nahosemenných i výtrusných dřevin: dendrologie 1, Praha, Academia, 352 p. ISBN 97880-200-1567-9.

OHMANN, L. F., 1979: Northeastern and north central forest types and their management In: Carey, J. H. Pinus strobus. In: Fire Effects Information System [Online]. c1993, [cit. 6.6.2012] Available: <http://www.fs.fed.us/database/feis/plants/tree/ pinstr/all.html\#31>.

PLÍVA, K., 1987: Typologický klasifikační systém ÚHÚL. ÚHÚL Brandýs nad Labem, 52 p.

QUITT, E., 1971: Mapa Klimatické oblasti ČSSR 1:500 000. Kartografické nakladatelství pro Geografický ústav Československé akademie věd Brno.

ŠIKA, A., 1976: Vejmutovka (Pinus strobus L.) v lesích ČSR, In: Študia o jehličnatých drevinách, Bratislava, Věda slovenskej akadémie vied, 281 p.

ŠINDELÁŘ, J., FRÝDL, J., 2004: Šlechtění a introdukce dřevin $\mathrm{v}$ ekologicky orientovaném LH. Lesnická práce, 2: 20-21. ISSN 1212-8449.

STATSOFT, Inc., 2007: Statistica for Windows. StatSoft, Tulsa, USA.

STRUVE, D. K., TALBERT J. T., MCKEAND S. E., 1984: Growth of rooted cuttings and seedlings in a 40-year-old plantation of eastern white pine. In: BURNS, R. M., HONKALA, B. H., 1990: Silvics Of North America Vol. 1 Conifers, Washington D.C., Agriculture Handbook 654, USDA Forest Service. $877 \mathrm{p}$.

TAUCHMAN, P., 201l: Výskyt a funkční účinky introdukovaných dřevin na ŠLP Kostelec nad Černými lesy, Disertační práce, FLD ČZU v Praze, $163 \mathrm{p}$.

ÚRADNÍČEK, L., 2003: Lesnická dendrologie I.: Gymnospermae, Brno, Mendelova zemědělská a lesnická univerzita v Brně, 70 p. ISBN 80-7157643-3.

VACULÍK, M., 2010: Inventarizace a management introdukovaných dřevin V PR Pavlino údolí, Diplomová práce, LDF MENDELU v Brně, 86 p.

WALDHERR, M., 2000: Die Strobe in Ostbayern (Niederbayern - Oberpfalz): Wachstum und waldbauliche Erfahrungen. Forst und Holz, 2: 3539. ISSN 0932-9315. 